Kaija Salmio utexaminerades år 1971 som filosofie magister vid Helsingfors universitet med botanik som huvudämne. Sedan år 1981 har hon arbetet som överinspektör vid Skolstyrelsen och som undervisningsråd vid Utbildningsstyrelsen. Hon disputerade för doktorsgraden vid Joensuu universitet år 2004. I sin avhandling behandlade hon de riksomfattande prov som hålls i slutskedet av den grundläggande utbildningen ur perspektivet den hållbara utvecklingens didaktik. I avhandlingen belyser hon utvecklingen inom utvärderingen och kopplingen till läroplansgrunderna.

Salmio har som koordinator och sakkunnig deltagit i internationella miljöprogram, bl.a. The Baltic Sea -project within Unesco Aspnet och The Globe-program.

KAIJA SALMIO

Utbildningsstyrelsen, Helsingfors, Finland

kaija.salmio@oph.fi

\title{
Hållbar utveckling i de nationella utvärderingarna av inläringsresultat i Finland
}

\author{
Abstract \\ This article examines how sustainable development has been defined in two Finnish National Core \\ Curricula for Basic Education for a considerable period of time, and how their Curricula objectives have \\ been achieved in two national tests in natural sciences. The objectives, test assignments and results \\ of the two tests have been analysed according to the principles of sustainable development, in what \\ ways the principles had been included in the assignments, and what were the pupils" results.
}

One of the outcomes was, that it was possible to teach sustainable development in different subjects as well as in different themes according to the two Finnish National Core Curricula. Based on national assessments of learning outcomes, however, pupils did not fully understand the whole process of sustainable development or its principles, even though they had a fair command of some details related to sustainable development. The reports on national tests lack a systematic analysis of learning the principles of sustainable development.

Most test assignments were related to the ecological dimension. The economic and cultural dimensions of sustainable development were not included to any significant extent in national assessments. The 2006 national assessment in the subject known as "environment and nature studies" was the first occasion where pupils carried out experimental group assignments. Their performances were assessed in terms of both progress of the process and knowledge of the content.

Research data consisted of two National Core Curricula for Basic Education, national tests in natural sciences held in the final $\left(9^{\text {th }}\right)$ grade of basic education and the results of these tests. The data were analysed through content analysis. 


\section{INLEDNING}

I denna artikel behandlar jag på basis av min doktorsavhandling (Salmio 2004) två finländska nationella prov i naturvetenskap och deras mål, innehåll och resultat ur den hållbara utvecklingens perspektiv. De nationella proven i naturvetenskaper bygger på grunderna för läroplanen, vars innehåll jag granskar ur den hållbara utvecklingens perspektiv.

Det fanns en strävan att effektivera funktionerna i de finländska skolorna på 1990-talet genom att avskaffa författningar. Samtidigt ändrades läroplanssystemet, som innehåller grunderna för läroplanen, som är ett nationellt dokument, samt kommun- och skolvisa läroplaner. De finländska läroplansgrunderna skiljer sig från den svenska läroplanen så, att de innehåller både de allmänna målen och de ämnesvisa målen och innehållen. Skolorna fick i och med reformerna mera beslutsrätt och ansvar för sin egen verksamhet, såsom t.ex. möjlighet att göra upp egna lokala läroplaner. Statsrådet (Undervisningsministeriet 1991, 1995 och 1999) inledde en reform av utvärderingarna som en del av förändringen, till vilka de nationella utvärderingarna hörde.

I texten använder jag termen nationellt prov, med vilket jag avser ett nationellt prov som genomförs enligt lagstiftningen. De nationella proven har inte samma status i Finland som t.ex. i Storbritannien, där de utvärderar hela årskursens kunskaper. I Finland är avsikten att genom nationella prov baserade på ett sampel bedöma hur målen för ett läroämne har uppnåtts.

Förenta Nationernas decennium för utbildning för hållbar utveckling 2005-2014 pågår som bäst. Även i Finland strävar vi efter att uppfylla målen för decenniet, och därför lanserades 2006 en ny nationell Strategi för hållbar utveckling. I detta arbete har tjänstemän i olika förvaltningar samt representanter för miljö- och konsumentorganisationer deltagit. I utformandet av strategin beaktades både nationella och internationella processer. Strategin innehåller planer för att öka samarbetet och nätverken. (Finlands kommission för hållbar utveckling 2006.)

I anslutning till strategin för hållbar utveckling har en separat Strategi för utbildning för hållbar utveckling utarbetats. Målet för den är att beakta alla den hållbara utvecklingens dimensioner i fostran och utbildning, så att de stöder barnens och ungdomarnas handlingar i ett ekoeffektivt och miljövänligt samhälle, i skapandet av rättvisa och i internationellt umgänge samt att få till stånd förändringar i vardagsrutinerna och engagemang för en hållbar livsstil. (Finlands kommission för hållbar utveckling 2006.)

\section{DEFINITION AV HÅLLBAR UTVECKLING}

Flera definitioner på hållbar utveckling har lagts fram. En av de mest citerade är Brundtlands (1987) i rapporten "World Commission on Environment and Development on Our Common Future". Brundtlands definition lyder "Sustainable development is development that meets the needs of the present without compromising the ability of future generations to meet their own needs". Hållbar utveckling skall samtidigt vara ekologiskt, ekonomiskt, kulturellt och socialt hållbar. Principen för ekologisk hållbarhet är att jordens ekosystem och andra funktioner i natursystemen bibehålls samt att biodiversiteten bevaras. I ekonomisk hållbarhet ingår hållbar produktion och att motverka förstörelse av naturen. Det är viktigt att sträva efter att konsumera ansvarsfullt och framför allt efter att minska konsumtionen.

Socialt hållbar utveckling innebär att värna om människans grundtrygghet och grundläggande behov. Man skall stöda individernas välmående och kompetens samt stärka det kollektiva sociala kapitalet, dvs. välfärden. Kulturellt hållbar utveckling strävar efter att utvidga förståelsen mellan nationella kulturer och att överföra kulturarvet till följande generationer. 
I hållbar utveckling behövs en kombination av flera vetenskapsgrenar och synvinklar för att en helhet skall bildas. I den grundläggande utbildningen betyder hållbar utveckling att man skapar en grund av olika läroämnen och temaområden, där observationer i naturen och i den byggda miljön samt globala fenomen inlemmas. Iakttagande av de olika aspekterna i hållbar utveckling kan främjas i studierna av alla naturvetenskaper.

I Tabell 1 presenteras en klassificering av hållbar utveckling i olika aspekter. Endast de läroämnen som behandlas i denna artikel är medtagna i klassificeringen.

Tabell 1. Olika aspekter av hållbar utveckling ur skolarbetets och undervisning-studier-lärandeprocessernas perspektiv, vilka alla måste beaktas i främjandet av hållbar utveckling enligt modell av Åhlberg (2004) och Salmio (2004).

\begin{tabular}{|c|c|c|c|}
\hline $\begin{array}{l}\text { Aspekt på hållbar } \\
\text { utveckling }\end{array}$ & $\begin{array}{l}\text { Kapitalslag som } \\
\text { skall skyddas och } \\
\text { som man måste } \\
\text { värna om }\end{array}$ & $\begin{array}{l}\text { Skolaktivitet, bl.a. } \\
\text { undervisning i } \\
\text { läroämnen, exempel }\end{array}$ & $\begin{array}{l}\text { Värden och värderingar } \\
\text { som ligger som grund }\end{array}$ \\
\hline $\begin{array}{l}\text { Ekologiskt hållbar } \\
\text { utveckling }\end{array}$ & $\begin{array}{l}\text { Naturens kapital, } \\
\text { bl.a. naturens } \\
\text { kretslopp, } \\
\text { ekosystemens } \\
\text { funktion, } \\
\text { biodiversiteten }\end{array}$ & $\begin{array}{l}\text { Biologi, geografi, natur- } \\
\text { och miljökunskap, fysik, } \\
\text { kemi, miljöfostran }\end{array}$ & $\begin{array}{l}\text { Människolivet har egen- } \\
\text { värde. Övriga organism- } \\
\text { ers liv har både egen- } \\
\text { värde och instrumentellt } \\
\text { värde. Naturen har både } \\
\text { egenvärde och } \\
\text { instrumentellt värde. }\end{array}$ \\
\hline $\begin{array}{l}\text { Ekonomiskt hållbar } \\
\text { utveckling }\end{array}$ & $\begin{array}{l}\text { Penningkapitalet, } \\
\text { infrastrukturen }\end{array}$ & $\begin{array}{l}\text { Fysik, kemi, biologi, } \\
\text { geografi }\end{array}$ & $\begin{array}{l}\text { Ekonomiska värden är } \\
\text { viktiga instrumentella } \\
\text { värden. }\end{array}$ \\
\hline $\begin{array}{l}\text { Socialt hållbar } \\
\text { utveckling }\end{array}$ & $\begin{array}{l}\text { Det socialt kapitalet, } \\
\text { familjen, vännerna, } \\
\text { samhället, nationen, } \\
\text { mänskligheten }\end{array}$ & $\begin{array}{l}\text { Lärande som gemensam } \\
\text { aktivitet, gemensam } \\
\text { uppbyggnad av kunskap, } \\
\text { anordnande av och } \\
\text { deltagande i } \\
\text { gemensamma } \\
\text { evenemang, } \\
\text { hälsokunskap }\end{array}$ & $\begin{array}{l}\text { De sociala värdena är } \\
\text { både egenvärden och } \\
\text { instrumentella värden. } \\
\text { Jämlikhet är ett viktigt } \\
\text { värde i ett demokratiskt } \\
\text { samhälle, som främjar } \\
\text { socialt hållbar utveckling. }\end{array}$ \\
\hline $\begin{array}{l}\text { Kulturellt hållbar } \\
\text { utveckling }\end{array}$ & $\begin{array}{l}\text { Kulturellt kapital, } \\
\text { intellektuellt kapital, } \\
\text { kreativt kapital }\end{array}$ & $\begin{array}{l}\text { Inlärning av } \\
\text { vetenskapligt, } \\
\text { teknologiskt, konstnärligt, } \\
\text { kulturellt tänkande och } \\
\text { handlande, bl.a. } \\
\text { undervisnings-, studie- } \\
\text { och läro-processer. } \\
\text { Fysik, kemi, biologi, } \\
\text { geografi }\end{array}$ & $\begin{array}{l}\text { De kulturella värdena är } \\
\text { både egenvärden och } \\
\text { instrumentella värden. }\end{array}$ \\
\hline $\begin{array}{l}\text { Mänskligt, hållbar } \\
\text { utveckling särskilt } \\
\text { förknippad med } \\
\text { hälsa }\end{array}$ & $\begin{array}{l}\text { Mänskligt kapital, } \\
\text { hälsa, miljö som } \\
\text { befrämjar hälsa }\end{array}$ & $\begin{array}{l}\text { Biologi, hälsokunskap, } \\
\text { vistelse i naturen }\end{array}$ & $\begin{array}{l}\text { Hälsan har både } \\
\text { egenvärde och } \\
\text { instrumentellt värde }\end{array}$ \\
\hline $\begin{array}{l}\text { Politiskt hållbar } \\
\text { utveckling }\end{array}$ & $\begin{array}{l}\text { Förtroendekapital, } \\
\text { trovärdighetskapital } \\
\text { statens och } \\
\text { kommunernas } \\
\text { förmåga att värna } \\
\text { om de mänskliga } \\
\text { rättigheterna, övriga } \\
\text { förpliktelser som } \\
\text { följer av } \\
\text { internationella och } \\
\text { nationella } \\
\text { överenskommelser }\end{array}$ & Samhällslära, geografi & $\begin{array}{l}\text { Ett gott liv har egenvärde. } \\
\text { Den hållbar utveckling } \\
\text { som stöder det och } \\
\text { ansluter sig till det samt } \\
\text { en god miljö har } \\
\text { instrumentellt värde. }\end{array}$ \\
\hline
\end{tabular}


Tabellen beskriver värden som ansluter sig till hållbar utveckling. De värden som ligger till grund för den här artikeln är hållbar utveckling, en god miljö och ett gott liv både för den nuvarande generationen och för kommande generationer. Utvecklingen av utvärderingen behandlas i ett vidare perspektiv än de utvärderingssätt som använts i utvärderingarna av inlärningsresultat.

I undervisnings-studie-inlärningsprocessen handlar det om att förverkliga värden (Åhlberg 2004). Värden är också allmänt centrala vid evaluering (House 1986, 1993; Linnakylä 1998; Norris 1994; Rossi, Lipsey \& Freeman 2004, 17; Scriven 1991, 1, 4-5; Sinkkonen \& Kinnunen 1994).

I motsats till vad som antas i traditionella utvärderingsundersökningar, är vetenskapen och forskarna inte värdefria (Guba \& Lincoln 1989, 128). Varje forskare skapar alltid egna värden för sitt arbete och att undvika subjektivitet är omöjligt (Brown 1988; Kansanen 1997; Nevo 1994). Varje forskare förstärker i sina undersökningar medvetet eller omedvetet sina egna uppfattningar, som påverkar materialet, arbetsmetoderna, resultaten och deras tolkning. Det är således inte möjligt att låta bli att beakta värdena hos de personer som ansluter sig till ett projekt. Att värdera är en nödvändig del av utvärderingsprocessen. I stället för en objektiv sanning finns det flera subjektiva sanningar, som kan förekomma samtidigt. (Mäntysaari 1999, 57.)

\section{UTVÄRDERING}

Utvärderingen i de finländska nationella proven har varit målutvärderingar, där man har utvärderat hur de mål som uppställs i grunderna har förverkligats. I utvärderingen ingår kontroll. En tydlig förändring i bedömningskulturen kan skönjas, när man övergått från minneskunskap till bedömning av mål och därifrån till värdepluralistiska modeller, där man betonar processcentrering (Guba \& Lincoln 1989).

Utvärdering definieras som ett systematiskt värdesättande eller meritgivande av ett visst föremål. Därmed förknippas ofta ett krav på förändring, med vilken man vill stöda lärande. (House 1986 och 1993; Kansanen 1997; Linnakylä 1998; Nevo 1994; Norris 1994; Scriven 1991; Scriven, Stake \& Eisner 1995; Sinkkonen \& Kinnunen 1994; Windham \& Chapman 1990). Målen för utvärdering och valen av kriterier samt sätten att strukturera är alltid värdebundna. Utvärderingar används både som källa för information och som redskap för riktningen av reformpolitiken (Scriven 1986; Temmes 1994). Därför är det nödvändigt att precisera syftet med utvärderingarna (Chelimspky \& Shadish 1997).

Syftet med utvärdering är då också att producera kunskap som kan användas för att utveckla verksamheten beträffande hållbar utveckling. Utvärderingarna har sina utgångspunkter i värde och nytta. En förändring förutsätter utvärdering, där utmaningen framför allt riktar sig mot utvärderarens förmåga. Förändringen antas främja lärande, för den kan motivera dem som deltar, och med den kan man få till stånd verkliga utvecklingsprojekt. Med utvärdering kan man också kontrollera inlärningens kvalitet (Conner, Ponting, Evans, \& Beynon 1991; Kansanen 1997; Lindquist 1999; Nevo 1994; Seppänen-Järvelä 1999, 92). En skicklig utvärderare är en skicklig skapare av förändring (Salmio 2004, 95 ja 114).

Frågan om bedömningens berättigande, definitionen av värdekriterierna, målen, behoven, de sociala idealen och den överenskomna standarden är central. Vem har rätt att definiera vilka värden som är de rätta? För vad bör utvärderingen användas, för att utveckla, belöna eller fatta beslut? Utvärderingen av varje objekt sker alltid i en viss kontext vid en viss tidpunkt (Guba \& Lincoln 1989). Hållbar utveckling ställer nya krav också på utvärderingen.

Utvärderingens rötter finns i gemensamt överenskomna värderingar och i de mål som styrs av dessa; grunden ligger däremot i systematisk och kompetent insamling och analys av kunskap, dvs. 
forskning. Utvärderingsresultaten får sin betydelse genom kloka och användbara slutsatser och genom att utvärderingskunskapen används som redskap i utvecklingen av utbildning och samhälle (Linnakylä \& Välijärvi 2005, 23).

Utveckling och utvärdering hör intimt samman. Syftet med både utveckling och utvärdering är att förbättra elevernas förståelse och uppnå växelverkan. Det är väsentligt att utvärderingen inte har betydelse som en lösryckt företeelse, utan att den är en del av skolans verksamhet (Kansanen 1997). I Finland bestämmer läroplansgrunderna vad som undervisas i skolan och utvärderingen berättar om arbetets resultat. Utvärderingsresultaten hjälper utvecklarna att välja ut utvecklingsföremålen rätt.

Processutvärdering räknas till utvecklande utvärdering. Dess främsta uppgift är att förbättra förståelsen och underlätta beslutsfattandet. Den uppfattas som en metod att bibehålla inlärningsnivån och med hjälp av den kontrolleras verksamhetens effektivitet och undervisningens nivå i skolorna (Patton 1997, 206-207; Scriven 1991).

\section{UNDERSÖKNINGENS UPPGIFT}

I artikeln utreds på vilket sätt den hållbara utvecklingens dimensioner har skrivits in i två läroplansgrunder, hur de förverkligas i två nationella prov i naturvetenskap och hur eleverna kunde hållbar utveckling $\mathrm{i}$ dem.

Jag behandlar prov i flera läroämnen år 1995 (Yrjönsuuri \& Salmio 1996) och i naturvetenskaper år 1998 (Rajakorpi 1999) ur den hållbara utvecklingens perspektiv. Jag jämför deras mål, uppgifter och resultat med läroplansgrundernas (Skolstyrelsen 1985; Utbildningsstyrelsen 1994), för de båda proven genomfördes enligt läroplansgrunderna. Jag behandlar också utvärderingen av naturoch miljökunskap som hölls år 2006 enligt samma principer, men presenterar inte resultaten här. Resultaten av utvärderingen blir färdiga i slutet av år 2007.

\section{UNDERSÖKNINGSMETODER}

Som forskningsmetoder för att analysera resultaten av provet i flera läroämnen (Yrjönsuuri \& Salmio 1996) och det nationella provet i naturvetenskaper (Rajakorpi 1999) använder jag kvalitativ dokument- och innehållsanalys. I kvalitativ undersökning betonas analys av materialet och inte hur materialet anskaffats, så att man med hjälp av undersökningen kan definiera värdet av väsentliga funktioner i hållbar utveckling. Värdesynpunkter och mångformade möjligheter accepteras och man strävar inte efter ett traditionellt objektivt resultat (Denzin \& Lincoln 2000; Hirsjärvi, Remes \& Sajavaara 1997; Patton 1990, 128).

Jag klassificerar de avsnitt i läroplansgrundernas (Skolstyrelsen 1985; Utbildningsstyrelsen 1994) läroämnesvisa mål, innehåll och resultat i naturvetenskaperna som ansluter sig till hållbar utveckling eller någon av dess fyra dimensioner (Brundtlands rapport 1987; Finlands kommission för hållbar utveckling 2006; Salmio 2004).

\section{FöRVERKLIGANDET AV HÅLLBAR UTVECKLING I NATURVETENSKAPERNA}

Hållbar utveckling förekommer i målen för flera läroämnen och temaområden i läroplansgrunderna för den grundläggande utbildningen (Skolstyrelsen 1985; Utbildningsstyrelsen 1994). Med temaområden avses viktiga teman som överskrider ämnesgränserna och som behandlas i flera olika läroämnen eller andra sammanhang i skolarbetet och av vilka ett är hållbar utveckling. 
I naturvetenskaperna betonas lärande genom att förstå. Eleverna har begränsade möjligheter att förstå det naturvetenskapliga perspektivet, eftersom läroplanerna i högre grad betonar minneskunskap än förståelse. (Bransford, Brown \& Cocking 2000, 9, 16.)

\section{Hållbar utveckling som en del av naturvetenskaperna i läroplansgrunderna}

I den grundläggande utbildningen betyder hållbar utveckling att man skapar en grund av olika läroämnen och temaområden, där observationer i naturen och i den byggda miljön samt globala fenomen inlemmas.

I läroplansgrunderna nämns inte hållbar utveckling just alls som en helhet, men en behandling av dimensionerna i hållbar utveckling och miljöfenomen ingår i många läroämnen, såsom natur- och miljökunskap, biologi, geografi, fysik, kemi och hälsokunskap. Läroplansgrunderna av år 1985 och av år 1994 ger goda möjligheter att genomföra hållbar utveckling. I läroplansgrunderna har jag valt endast de mål och innehåll som stöder dimensionerna i hållbar utveckling.

Naturvetenskaperna som läroämnen har i grunderna uppfattats som mycket vidsträckta vetenskapsgrenar, där dessutom attityder, problemlösnings- och slutledningsförmåga samt aktivitetsutvecklande färdigheter har inlemmats i avsikt att stärka det vetenskapliga tänkandet. Att man behärskar begreppen anses i alla naturvetenskaper vara en viktig grundförutsättning. Människans världsbild och ansvar för miljön betonas också i målen för naturvetenskaperna. Förmåga att skaffa information fanns redan i läroplansgrunderna år 1985 (Skolstyrelsen 1985).

I läroplansgrunderna (Skolstyrelsen 1985, 161) förutsattes att undervisningen skulle ge kunskap om fysikaliska och kemiska fenomen och dessutom bl.a.

- kunskap om deras betydelse i naturen och i det praktiska livet

- väcka elevernas intresse och aktivitet att skaffa egna kunskaper

- ge eleverna färdigheter att skapa sig en världsbild

- utveckla bl.a. problemlösnings- och samarbetsförmåga

I lärokursernas innehåll bekantade man sig med bl.a. miljön och att förstå miljön. Hållbar utveckling fanns redan som mål i läroplansgrunderna 1985. Innehållen tillät så ofta som möjligt ett experimentellt tillvägagångssätt, bl.a. observation, värmeenergi, strålning och organisk kemi (Skolstyrelsen 1985, 162-164).

Det allmänna målet för biologiundervisningen var att ge eleverna färdigheter att skapa sig en naturvetenskaplig världsbild. Målen för den kunskapsmässiga fostran var bl.a. att

- bekanta eleverna med den levande naturen och med den grundläggande begreppsapparaten i biologi

- lära ut människans uppbyggnad och livsfunktioner samt de centrala ekologiska lagbundenheterna. (Skolstyrelsen 1985, 165-172.)

Till målen för den färdighets- och attitydmässiga fostran i biologi hörde att

- utveckla förmåga att använda de inlärda begreppen, observationerna och de inhämtade kunskaperna för att dra slutsatser och ett naturvetenskapligt tänkesätt

- väcka ansvaret för den egna hälsan och få eleverna att förstå sitt ansvar för att skydda livsmiljön och livet samt människans ansvar som förändrare av naturen och utnyttjare av naturresurserna.

Innehållet i hållbar utveckling fanns i hög grad med i biologi och geografi. Skyddet av livet är ett värde, som har skrivits in i målen för biologi och geografi. De allmänna målen för undervisningen i geografi (Skolstyrelsen 1985, 165-166) var att ge eleverna färdigheter för att kunna skapa sig en världsbild som motsvarar verkligheten. Undervisning som diskuterade nya synvinklar och alternativa lösningar gjordes möjlig. Här ingick ekonomisk och social hållbarhet. Målen för den 
kunskapsmässiga fostran var bl.a. att

- eleverna skulle förstå de möjligheter som miljön bjuder på och effekterna av de tillgängliga naturresurserna på människans ekonomiska, sociala och politiska verksamhet.

Till målen för den färdighets- och attitydmässiga fostran i geografi hörde bl.a. att

- stärka förståelse och respekt, samarbete och fred bland eleverna

- betona människans ansvar för den egna livsmiljön och för jordklotets naturresurser.

Läroplansgrunderna 1994 definieras som en dynamisk process, som skulle reagera på bl.a. utvärderingsresultat. Läroplansgrunderna avviker från tidigare riksomfattande grunder i två avseenden: de var mycket liberala och godkände för första gången tillämpningen av olika pedagogiska alternativ i skolorna. Man ville bl.a. främja förståelsen för processer och experimentella metoder hos eleverna (Utbildningsstyrelsen 1994, 89).

Miljöfrågor finns i läroplansgrunderna både i fysikens och i kemins innehåll. Målen för dem är bl.a. problemlösnings- och beslutsfattningsförmåga och förmåga att tillämpa. Ett mål för studierna i fysik (Utbildningsstyrelsen 1994, 88) är bl.a. att

- eleverna skall kunna diskutera fenomen i fysiken och tillämpa fysikalisk kunskap $i$ frågor kring natur och miljö, i problemlösning och i beslutsfattande.

Ett mål för studierna i kemi är de värden som finns inskrivna i läroplansgrunderna (Utbildningsstyrelsen 1994, 89). Målen bl.a. är att eleven

- lär känna kemin i sin livsmiljö

- lär sig en terminologi med vilken han eller hon kan diskutera naturen, miljön och teknologi

- lär sig tillämpa kemisk kunskap så att den kan användas t.ex. till att klargöra frågor och lösa problem kring natur och miljö

- kan bedöma miljökonsekvenserna av människans verksamhet och utveckla ansvarsfullhet $i$ användningen av kemiska preparat och $i$ avfallshanteringen.

Målen för studierna i biologi i läroplansgrunderna 1994 (Utbildningsstyrelsen 1994, 84-85) är att eleven bl.a.

- förstår de orsaks- och verkansammanhang som råder $i$ naturen

- lär sig ta ansvar för sin egen hälsa och anammar sunda levnadsvanor

- lär sig känna igen förändringar i naturen, söka orsakerna och fundera över deras följder

- lär sig bedöma betydelsen av sina val och söka metoder att minska de skadliga miljöverkningarna.

Målet för studierna i geografi är i läroplansgrunderna 1994 (Utbildningsstyrelsen 1994, 83-84) att eleverna bl.a

- lär sig att skaffa aktuell kunskap på ett mångsidigt sätt

- lär sig förstå att varje människa har ansvar för miljön och att människans framtid beror av de beslut som fattas i mänskliga samfund.

I läroplansgrunderna 1994 (Utbildningsstyrelsen 1994) skedde inga innehållsliga och teoretiska förändringar jämfört med grunderna 1985 (Skolstyrelsen 1985). Nytt i biologi var att eleverna lärdes att söka metoder att minska på de skadliga miljöverkningarna. Ansvaret för miljön betonades såväl i biologi och geografi som i fysik och kemi.

\section{Hållbar utveckling som temaområde i läroplansgrunderna}

Integreringen har i de finländska läroplansgrunderna formen av temaområden. I läroplanerna för de enskilda ämnena är syftet att sammanföra enskilda begrepp, färdigheter och värden så, att de kan komplettera varandra och så att man i stället för separata delar kan få helhetsbetonade och sammanhängande kunskapshelheter (Meri 1992, 17-18; Åhlberg 2004). 
Grunderna för läroplanen 1994 (Utbildningsstyrelsen 1994, 81) innehöll en klar integrationssträvan. Klarast syntes denna strävan i målen för läroämnena fysik och kemi. I läroplansgrunderna år 1994 ledde betoningen av läroämnena till att de formella målen blev lösryckta och till att grunderna inte förmådde integrera innehållen i läroämnena. Detta gällde också hållbar utveckling. Nixon $(1992,51)$ påvisade samma sak i sina egna undersökningar.

Temaområdenas mål och innehåll har formulerats på en allmän nivå, men strävan har ändå varit att koppla dem till elevernas erfarenhetsvärld (Skolstyrelsen 1985; Utbildningsstyrelsen 1994). Temaområden var tidigare inte obligatoriska. Förändringen kom i samband med läroplansgrunderna år 2004 (Utbildningsstyrelsen 2004), där temaområdenas ställning förstärktes. Numera skall temaområdena tas i upp i samband med undervisningen av de obligatoriska läroämnena.

Temaområdena är ett mellanting mellan helhetsläroplanen och den ämnesvisa läroplanen, eftersom de kan undervisas i samband med ett läroämne eller som fristående helheter. Temaområdenas integrerande innehåll tas i allmänhet upp i samband med undervisningen av läroämnena, och är då svåra att beakta (Nixon 1992, 51.)

Förverkligandet av hållbar utveckling kan medföra problem, för den allmänbildande utbildningen är starkt läroämnesbetonad och läroplansgrunderna innehåller rikligt med läroämnesvisa mål. Trots det håller hållbar utveckling på att bli en viktig faktor inom utbildningen, både i undervisningen och i vardagsrutinerna.

En ändamålsenlig användning av temaområden förutsätter överskridning av läroämnesgränserna så, att aktuella och viktiga helheter kan gestaltas och förstås. I grunderna för läroplanen 1994 (Utbildningsstyrelsen 1994, 88-89) formuleras integreringen bäst i målen och innehållet för undervisningen i fysik och kemi. Om dessa konstateras bl.a. att

- fysik- och kemiundervisningen skall hjälpa eleven att gestalta helheter över ämnesgränserna.

I målen för kemiundervisningen (Utbildningsstyrelsen 1994, 86) finns bl.a. integrerande element och element som hänför sig till hållbar utveckling:

- Eleverna behärskar en terminologi som gör det möjligt för dem att diskutera frågor som rör naturen, miljön och teknologin.

Hargreaves (1994) frågar motiverat, om läroplanens temaområden är ett av de områden där skillnaderna mellan skolorna är störst. Svaret kan vara jakande, eftersom tiden går åt till att undervisa läroämnets lärostoff.

\section{Hållbar utveckling i de nationella proven i naturvetenskap}

Ämnesvisa prov motiveras i Utbildningsstyrelsen med att grundskolan undervisar i de läroämnen som den tidigare grundskolelagen (476/1983) och den nuvarande lagen om grundläggande utbildning (628/1998) förskriver; dessa läroämnen utgör en stor del av läroplansgrunderna.

I de nationella utvärderingarna användes främst traditionella kvantitativa undersökningsmetoder. Syftet med utvärderingarna var inte endast att kontrollera de kvantitativa kunskaperna, utan att också få fram utvecklingsmål och nyttosynpunkter.

Båda proven hölls för 15-16-åringar, elever i nionde årskursen som avslutade den grundläggande utbildningen. I det förstnämnda provet deltog över 3300 elever och i det senare närmare 3400 elever. Provet i natur- och miljökunskap hölls i början av den femte årskursen hösten 2006, för omkring 11-åriga elever. I det deltog c:a 5600 elever. 


\section{Provet i flera läroämnen år 1995}

I provet i flera läroämnen ville man avvika från ämnesindelningen och därför genomfördes provet som ett ämnesövergripande prov (Yrjönsuuri \& Salmio 1996). Provet förverkligades enligt grunderna för läroplanen 1994, fastän eleverna hade studerat enligt grunderna för läroplanen 1985. Med hjälp av provet ville man rikta in undervisningen av läroämnena mot tillämpande inlärning och besluts- och verksamhetssituationer. Därför skulle provet innehålla rikligt med andra mål än sådana som ansluter sig till läroämnenas innehåll. Provet var till största delen integrativt. Av eleverna förutsattes personliga uppfattningar om frågor som inte anknöt till något enskilt ämne, såsom ålderdom, lärande och att klara sig i livet.

Syftet var att utvärdera hur eleverna i grundskolans slutskede kan kombinera och tillämpa saker som de lärt sig i olika läroämnen och motivera sina val. Provet innehöll stoff från biologi, geografi, huslig ekonomi, gymnastik, elevhandledning, samhällslära och kemi. Synvinkeln i uppgifterna var människobilden som grund för handlandet, hälsans betydelse, växelverkan mellan människan och miljön för den mänskliga verksamheten. (Yrjönsuuri \& Salmio 1996, 391.)

Bedömningsgrunder för uppgifterna var beaktandet av utgångsläget och analysfärdigheterna, granskningens mångsidighet, motiveringen och logiken. Eleverna kunde tillämpa, kombinera och motivera sina lösningar nöjaktigt eller försvarligt. Ämnen som intresserar de unga behärskades bra, t.ex. den hormonella verksamheten, preventivmedel och de risker som ansluter sig till alkohol och tobak. Ungdomarna var beredda att arbeta för miljön och utförde varje vecka handlingar som sparar miljön, men kunde inte motivera varför (Salmio 2004.)

Provet i flera ämnen visade att skolan inte är bra på att lära för livet (Yrjönsuuri \& Salmio 1996, 391-406.). Det räcker inte med en naturvetenskaplig uppfattning, utan för att stöda de ungas växande behövs också egen vilja och positiva attityder, med hjälp av vilka eleverna kan beredas på att granska problem, samarbeta och klara nya situationer. Bl.a följande uppgift är ett exempel på dessa mål:

"Vad beror det på att antalet människor $i$ världen har ökat explosionsartat under de senaste 100 åren?" Till uppgiften anslöt sig ett illustrerande stapeldiagram.

Cirka $80 \%$ av eleverna svarade ingenting eller mycket dåligt på befolkningsexplosionen. Tolkningsuppgifter, såsom föregående exempel och en uppgift där man skulle tolka innehållet i en befolkningspyramid, visade sig vara svåra. Eleverna hade lösryckta kunskaper om många detaljer i hållbar utveckling, men kunde inte placera in dem i ett vidare sammanhang.

Den ekonomiska dimensionen i hållbar utveckling behandlades i uppgiften om befolkningsexplosionen och i en annan uppgift, där kommunala beslutsfattare skulle ta ställning till hur en udde $\mathrm{i}$ naturskick skulle användas. Eleven skulle motivera om udden skulle bebyggas eller bevaras som rekreationsområde. (Yrjönsuuri \& Salmio 1996.)

Eleverna kunde t.ex. redogöra för hur mässlingen sprids och hur rökning påverkar fostret, med de förstod inte deras betydelse i människans livsfunktioner (Yrjönsuuri \& Salmio 1996, 394-396).

I bakgrunden för Yrjönsuuris och Salmios $(1996,398)$ artikel finns uppfattningen om betydelsen av ett gott liv och en god miljö. Värdena framgår i artikeln bl.a. av en uppgift som gäller mobbning. Över hälften av eleverna godkände inte mobbning.

Du och dina klasskamrater vet att en elev i er klass mobbar eleverna $i$ de lägre klasserna på olika sätt. Mobbaren är försiktig så att lärarna inte skall märka något. Vad gör du? Ringa in ett alternativ. 
a. Jag bryr mig inte om hela saken.

b. Jag vågar inte blanda mig $i$ saken.

c. Jag talar med mobbaren om saken.

d. Jag berättar för läraren/rektorn.

e. Jag försvarar dem som mobbas.

f. Något annat. Vad?

\section{Utvärderingen av inlärningsresultat i naturvetenskap år 1998}

Utvärderingen av inlärningsresultat i naturvetenskap år 1998 i grundskolans 9 klass var ett nationellt prov i fysik, kemi, biologi och geografi. Syftet med utvärderingen var att klargöra hur målen hade uppnåtts samt nivån på kunskaperna i naturvetenskap i grundskolans slutskede. Dessutom producerades information som behövdes för att utveckla läroplanen och bedömdes hur jämlikheten i utbildningen har förverkligats. (Rajakorpi 1999, 114.)

Elevernas inlärningsresultat utvärderades ämnesvis med basuppgifter, tillämpande uppgifter och integrativa, kombinerade uppgifter i naturvetenskap (Rajakorpi 1999, 26, 28). I denna artikel behandlas endast uppgifterna i biologi och geografi samt kombinationsuppgifterna, som har dimensioner som anknyter till hållbar utveckling.

Vid tiden för provet i naturvetenskap år 1998 användes 1994 års läroplansgrunder (Utbildningsstyrelsen 1994). Av målen i biologi hade man till provet valt ekosystemets funktion, människans biologi och människan och miljön. Av målen för undervisningen i geografi hade man valt planeten jorden och dess särdrag, världsatlasen och tolkning och användning av scheman som kunskapskälla (Rajakorpi 1999, 27.)

Biologins centrala innehåll, bl.a. sexualiteten, människans levnadslopp från födelse till död, näringen och miljön, behandlades i uppgifterna. I läroplansgrunderna betonas färdigheter i att skaffa och behandla kunskap, men dessa användes inte i utvärderingen av inlärningsresultaten. (Rajakorpi 1999, 32-34.)

Eleverna fick i biologi (Rajakorpi 1999) endast besvara frågor som gällde den ekologiska dimensionen i hållbar utveckling, såsom i följande uppgift:

Vilket av följande påståenden är inte sant?

a. I naturliga ekosystem råder en viss balans.

b. Ju färre arter det finns $i$ ett ekosystem desto hållbarare är det ekologiskt.

c. Människans verksamhet inverkar olika i olika ekosystem.

d. Människan kan minska förstörelsen av miljön genom sitt eget handlande.

e. Det är inte möjligt för människan att snabbt avhjälpa de skador som åsamkats ekosystemet.

I de tillämpande uppgifterna i biologi (Rajakorpi 1999) ingick följande uppgift:

Besvara $i$ korthet följande frågor:

a. Varifrån härstammar den energi som finns $i$ rågbröd?

b. I vilken form förekommer energin i rågbrödet?

c. Hur når energin t.ex. muskelcellerna i handen?

d. Hur frigörs energin i muskelcellerna?

I de tillämpande uppgifterna i geografi (Rajakorpi 1999) ingick en uppgift med grafik över mängden nederbörd och temperaturen i Bergen och Villmanstrand per månad. Eleverna skulle jämföra diagrammen och dra slutsatser om de klimatologiska förhållandena på de både orterna.

Tyngdpunkten i uppgifterna låg på naturlig geografi. Kopplingar till samhället och till miljön saknades. I geografiuppgifterna ingick inte heller uppgifter som behandlar informationssökning eller åskådliggörande av geografiskt material. Uppgifterna förutsatte inte heller tolkning av kartor, 
utan eleverna förutsattes endast känna igen kartsymboler. (Rajakorpi 1999, 34-38.) Att tolka och förstå kartor är trots detta ett viktigt undervisningsmål.

Ett viktigt mål för de kombinationsuppgifter som ingick i provet i naturvetenskap var experiment, men inte sådana där eleverna arbetade självständigt. I de ämnesöverskridande uppgifterna testades observationsförmågan, klassificeringen, förståelsen och tolkningen av resultat samt slutledningsförmågan. Grundskolans teman i fysik och kemi var bl.a. växelverkan, energi och processer. De ämnesöverskridande uppgifterna kunde vara uppgifter som mäter miljöuppfattningar och handlingssätt som bygger på kunskap om miljön. Läroplansgrundernas värderelaterade mål hade lämnats utanför denna nationella utvärdering. (Rajakorpi 1999, 45-46.)

Utvärderingen av provet i naturvetenskap visade att eleverna behärskade basstoffet i biologi nöjaktigt, men basstoffet i geografi endast försvarligt. Resultaten i de tillämpande uppgifterna var försvarliga. Eleverna tycker om elevcentrerade arbetssätt och problemcentrerad undervisning. I undervisningen borde ingå mera färdigheter för experimentellt arbete och ett undersökande grepp, eftersom dessa ökar motivationen. Mera uppmärksamhet borde ägnas åt att förstå och tillämpa och att framställa inhämtad kunskap. (Rajakorpi 1999, 81, 117, 120-121.)

\section{Utvärderingen av inlärningsresultat i miljö- och naturkunskap år 2006}

Syftet med utvärderingen i miljö- och naturkunskap var att undersöka hur bra eleverna hade uppnått målen för läroämnet under de fyra första årskurserna. Miljö- och naturkunskap är ett integrativt läroämne som i årskurserna 1-4 innehåller stoff från biologi, geografi, kemi, fysik och hälsokunskap. Det var fråga om en utvärdering i miljö- och naturkunskap enligt de nya grunderna för läroplanen (Utbildningsstyrelsen 2004). Utvärderingen skulle även kartlägga utgångsnivån och ge information för utvecklandet av undervisningen i läroämnet.

Ett mål för utvärderingen av inlärningsresultat i miljö- och naturkunskap var att beakta integreringen och förståelsen och i provet togs därför med uppgifter som mätte dessa. I provuppgifterna ville man i enlighet med läroplansgrunderna (Utbildningsstyrelsen 2004) ägna uppmärksamhet åt användningen av ett naturvetenskapligt tänkesätt och förståelsen av fenomen och begrepp. Syftet med uppgifterna var att ta reda på hur ett undersökande och problemcentrerat arbetssätt förverkligas i läroämnet. I provet ingick två delar: individuella uppgifter och experiment i grupp. De individuella uppgifterna utfördes och bedömdes individuellt, men experimenten i grupp utfördes och bedömdes i grupp.

Med valet av de experimentella uppgifterna, där eleverna arbetade självständigt som grupp, ville man visa lärarna och eleverna hur de begrepp och principer som behandlas i studierna visar sig i praktiken, i en cykel. I gruppuppgifterna gjordes även observationer om vattnets aggregationstillstånd.

Dimensionerna i hållbar utveckling utvärderades i individuella uppgifter, där eleverna skulle avläsa en väderlekskarta och svara på frågor om vaccinering, närningskedjan, avfallssortering och återvinning.

\section{Värden som anknyter till hållbar utveckling i de nationella utvärderingarna}

Värdena bygger på Förenta Nationernas deklaration om de mänskliga rättigheterna, även om detta inte specificeras i texten (Skolstyrelsen 1985; Utbildningsstyrelsen 2004).

I Yrjönsuuris och Salmios $(1996,398,401)$ prov i flera läroämnen anses det viktigt att främja ett gott liv och en god miljö. Dessa värden speglas i uppgiften om mobbning och också i uppgiften om elevernas attityder till framtiden. De ungas pessimistiska inställning till framtiden var oroväckande, eftersom den berättar om en hopplös världsbild och små förväntningar på att klara sig. Det är skolans uppgift att stödja uppkomsten av en positiv framtidsbild hos de unga. Att de unga var intresserade av att arbeta för miljön var positivt. 
I många rapporter om Utbildningsstyrelsens utvärderingar av inlärningsresultat är jämlikheten i utbildningen det enda värde som granskas. Till exempel i Rajakorpis $(1999,46)$ rapport konstateras t.ex. att:

"de värdemål som skrivits in i grunderna för läroplanen har utelämnats från detta provpaket, eftersom de är så svåra att testa."

\section{Resultaten av de nationella utvärderingarna}

Hållbar utveckling och dess dimensioner har allt sedan 1970-talet ingått i grunderna för läroplanen (Kommittébetänkande 1970:A4; Skolstyrelsen 1985; Utbildningsstyrelsen 1994 och 2004). Möjligheter att använda dimensionerna i hållbar utveckling i de nationella proven har funnits, men de har utnyttjats ytterst begränsat. Strävan efter hållbar utveckling framställs inte som ett medvetet mål. Inte i en enda nationell utvärdering av inlärningsresultat har hållbar utveckling behandlats som ett helt fenomen, fastän detaljkunskapen ofta var medelgod. De uppgifter som förutsatte tillämpning visade sig vara svåra.

Enligt strategin för fostran och utbildning i hållbar utveckling (Finlands kommission för hållbar utveckling 2006) bör alla aspekter av hållbar utveckling, ekologiska, ekonomiska, sociala och kulturella följas upp, utvärderas, undersökas och utvecklas integrerat och samtidigt. Så har inte skett, utan utvärderingsrapporterna innehåller separata uppgifter och resultat från olika delområden inom hållbar utveckling. Många delområden som är viktiga för läroämnet saknas. Endast $\mathrm{i}$ uppgifterna i provet i flera läroämnen (Yrjönsuuri \& Salmio 1996) försökte man få fram hur det individuella och gemensamma ansvaret för miljön förverkligas.

Den största delen av de uppgifter som anknöt till hållbar utveckling representerade den ekologiska dimensionen, den som undervisas mest i skolorna. Några uppgifter anknöt till den sociala dimensionen, men inte i tillräcklig grad. Minst belystes den ekonomiska dimensionen i de nationella prov som behandlades.

Ett exempel på den sociala dimensionen i hållbar utveckling är mobbning. Mer än hälften av eleverna godkände inte mobbning. (Salmio 2004; Yrjönsuuri \& Salmio 1996.) Mobbning ingick också i provet i miljö- och naturkunskap år 2006, där företeelsen diskuterades i grupp.

Hittills har värdena och den globala aspekten inte ansetts tillräckligt viktiga i de nationella proven. Också i rapporterna saknas värdetänkande och värderesonemang nästan helt.

Experimentellt arbete har ingått i målen för alla tre läroplaner (Skolstyrelsen 1985; Utbildningsstyrelsen 1994 och 2004), men i de nationella proven har ingått mycket lite sådana uppgifter. De experimentella uppgifterna som eleverna utförde i grupp i provet i miljö- och naturkunskap byggde på gemensamt lärande, som är en del av den sociala dimensionen i hållbar utveckling. Det var också första gången som själva processen bedömdes. Gemensamt lärande förverkligades endast $\mathrm{i}$ experimenten i grupp i utvärderingen av inlärningsresultat i miljö- och naturkunskap.

Utbildningsstyrelsens huvudsakliga syfte i de nationella utvärderingarna har varit att bedöma hur eleverna behärskar innehållet i läroämnet. Tyngdpunkten i uppgifterna har varit på behärskningen av läroämnets innehåll och om det har också i allmänhet erhållits god information. I ingetdera av de nationella proven förverkligades de övriga målen, t.ex. studiefärdigheter och problemlösningsfärdigheter, fastän de också ingick i de ämnesvisa målen. De nationella proven innehölls sällan en integrerande synvinkel, trots att alla läroämnen innehåller lärostoff som förutsätter integrering och som stöder en hållbar utveckling. 


\section{GRANSKNING}

När utvärdering används som instrument för något ändamål, borde den bli viktig för dem som utvärderas. Då leder utvärderingens resultat till utvecklingsåtgärder eller till ett annat sätt att utnyttja resultaten. Därför borde man i utvärderingen koncentrera sig på frågor av nationell vikt. De nationella proven var och är ett medel för att driva de politiska och ekonomiska mål som administrationen eftersträvar. Målet var att få nationell information om vad eleverna kan i skolorna. Ett annat mål var att genom utvärderingarna få hjälp för det praktiska skolarbetet. (Salmio 2004.)

Genom att få arbeta självständigt med experimentella uppgifter får eleverna nya erfarenheter av naturvetenskap och teknologi. Positiva erfarenheter eftersträvades med de experimentella uppgifterna i miljö- och naturkunskap, i vilka ingick processutvärdering och utvecklande utvärdering (Juuti 2005, 12; Lavonen 1996; Patton 1997; Yli-Panula 2005). Hållbar utveckling som temahelhet förutsätter överskridning av ämnesgränderna så att helheten kan förstås.

Att lära och att tillämpa kunskap är i klassen en social händelse. Till det experimentella arbetet hör därför också att konstruera kunskapen socialt, i vilket språket spelar en viktig roll. Därför bör eleverna uppmuntras att diskutera med nya begrepp och tillämpa principerna i praktiska situationer när de gör elevarbeten, framhåller Lavonen $(1996,97)$.

I utvärderingsrapporterna motiveras målen knappast alls. Motiveringar förekommer inte heller i de nationella grunderna för läroplanen. I vilken mån de nationella prov som anknyter till naturvetenskaperna har varit till nytta för skolorna är okänt. Linnakylä ja Välijärvi $(2005,23)$ betonar betydelsen av att använda utvärderingsresultaten för att utveckla undervisningen, något som inte har gått att påvisa i dessa prov. Det kan bero på ett otillräckligt nationellt responssystem eller på att kvaliteten i den grundläggande utbildningen inte har varit föremål för särskild uppmärksamhet vid tiden för proven.

Utvärdering är växelverkan (Patton 1997). Därför borde det ingå mera växelverkan i de finländska proven. På så sätt kunde också inlärningsresultaten bli kvalitativt bättre (Conner \& al. 1991). Processutvärdering genomfördes i utvärderingen av inlärningsresultat i miljö- och naturkunskap år 2006. Den stöder sig på en gemensam verklighet och kontext (Guba \& Lincoln 1989).

Hållbar utveckling kan genomföras på ett positivt sätt endast om människorna betraktar de värden som ansluter sig till hållbar utveckling som positiva och om hållbar utveckling ses som ett globalt fenomen.

\section{KÄLLOR}

Bransford, J.D., Brown, A.L. \& Cocking, R.R. (Eds.) 2004. Miten opimme. Aivot, mieli, kokemus ja koulu. Helsinki: WSOY.

Brown, S. 1988. Assessment: A Changing Practice. In S. Brown \& H. Black (Eds.) Assessment: $A$ Changing Practice (pp. 1-16). Edinburgh: Scottish Press Academic.

Bruntland, G. (Ed.) (1987). Our common future: The World Commission on Environment and Development. Oxford: Oxford University Press.

Chelimsky, E. \& Shadish, W. R. (Eds.) 1997. Evaluation for the $21^{\text {st }}$ Century. A handbook. Thousand Oaks: Sage.

Conner, C., Ponting, D., Evans, M. \& Beynon, S. 1991. Assessment and Testing in the Primary School. School Development and the Management of the Change Series: 8. Cambrigde: The Falmer Press.

Finlands kommission för hållbar utveckling. 2006. Strategi och verksamhetsplan för fostran och utbildning i hållbar utveckling 2006-2014. Helsingfors: Edita Prima Oy. 
Grundskolans läroplanskommittés betänkande I. Grunderna för läroplan. 1970: A4.

Helsingfors: Statens tryckericentral.

Grundskolelag. 27.5.1983/476. Helsingfors.

Guba, E. \& Lincoln, Y. S. 1989. Fourth Generation Evaluation. Newbury Park: Sage.

Hirsjärvi, S., Remes, P. \& Sajavaara, P. 1997. Tutki ja kirjoita. Helsinki: Kirjayhtymä.

Hargreaves, D. H. 1994. The new Professionalism: Synthesis of Professional and Institutional Development. Teaching and Teacher Education 10 (4), 423-438.

House, E. R. 1986. How We Think about Evaluation. In E. R. House (Ed.) New Directions in Educational Evaluation (pp. 31-48). East Sussex: The Falmer Press.

House, E. R. 1993. Professional evaluation: Social impact and political consequences. Newbury Park: Sage.

Kansanen, P. 1997. Opetusprosessin arviointi. In R. Jakku-Sihvonen (Ed.) Onnistuuko oppiminen -oppimistuloksien ja opetuksen laadun arviointiperusteita peruskoulussa ja lukiossa (pp. 429-436). Opetushallitus. Arviointi 3/1997.

Lag om grundläggande utbildning. 21.8.1998/628. Helsingfors.

Lavonen, J. 1996. Fysiikan opetuksen kokeellisuus ja mittausautomaatio. University of Helsinki. Report Series in Physics. HU-P-D64. Helsinki: Oy Edita Ab.

Lindquist, T. 1999. Evaluaation uskottavuus. In R. Eräsaari, T. Lindquist, M. Mäntysaari \& M. Rajavaara (Eds.) Arviointi ja asiantuntijuus (pp. 106-118). Tampere: Yliopistokustannus University Press.

Linnakylä, P. 1998. Koulutuksen kansallisen ja kansainvälisen arvioinnin haasteita. Kasvatus 29 (2), 175-189.

Linnakylä, P. \& Välijärvi, J. 2005. Kansainvälinen arviointiyhteistyö hyödyttämään kansallista arviointia. In H.K. Lyytinen \& A. Räisänen (Eds.) Kehittämissuuntaa arvioinnista (pp. 13-25). Koulutuksen arviointineuvoston julkaisuja 6. Jyväskylä: Jyväskylän yliopistopaino,

Meri, M. 1992. Miten piilo-opetussuunnitelma toteutuu. Helsingin yliopiston opettajankoulutuslaitos. Tutkimuksia 104.

Mäntysaari, M. 1999. Arviointitutkimuksen taustaoletukset. In R. Eräsaari, T. Lindquist, M. Mäntysaari \& M. Rajavaara (Eds.) Arviointi ja asiantuntijuus. (pp. 54-68). Tampere: Yliopistokustannus.

Nevo, D. 1994. Combining internal and external evaluation: A case for school-based evaluation. Studies in Educational Evaluation. Vol. 20, 87-98.

Nixon, J. 1992. Evaluating the Whole curriculum. Milton Keynes. Philadelphia: Open University Press.

Norris, N. 1994. Curriculum evaluation. Manuscript.

Patton, M. Q. 1997. Utilization-Focused Evaluation. The New Century Text. Edition 3. Thousand Oaks: Sage.

Rajakorpi, A. (Ed.) 1999. Peruskoulun 9. -luokkalaisten luonnontieteiden oppimistulosten arviointi. Keväällä 1998 pidetyn kokeen tulokset. Opetushallitus. Oppimistulosten arviointi 2/1999. Helsinki: Yliopistopaino.

Rossi, P., Lipsey, M. \& Freeman, H. 2004. Evaluation. A systematic approach. $7^{\text {th }}$ edition. London: SAGE.

Salmio, K. 2004. Esimerkkejä peruskoulun valtakunnallisista arviointihankkeista kestävän kehityksen didaktiikan näkökulmasta. Joensuun yliopisto. Kasvatustieteellisiä julkaisuja N:o 98.

Scriven, M. 1986. Evaluation as a Paradigm for Educational Research. In E. R. House (Ed.) New Directions in Educational Evaluation (pp. 53-67). East Sussex: The Falmer Press.

Scriven, M. 1991. Evaluation thesaurus. $4^{\text {th }}$ edition. London: SAGE.

Scriven, M., Stake, R. \& Eisner, E. 1995. Curriculum Evaluation. In W. F. Pinar, W. M. Reynolds, P. Slattery \& P .M. Taubman (Eds.) Understanding Curriculum. An Introduction to the Study and Contemporary Curriculum Discourses. Studies in the Postmodern Theory of Education. Vol. 17 (pp. 732-744). New York: Peter Lang. 
Seppänen-Järvelä, R. 1999. Kehittämistyö ja arviointi. In R. Eräsaari, T. Lindquist, M. Mäntysaari \& M. Rajavaara (toim.) Arviointi ja asiantuntijuus (pp. 90-105). Tampere: Yliopistokustannus.

Sinkkonen, S. \& Kinnunen, J. 1994. Arviointi ja seuranta julkisella sektorilla. Kuopion yliopisto. Terveyshallinnon ja -talouden laitos. Kuopion yliopiston julkaisuja E. Yhteiskuntatieteet 22.

Skolstyrelsen 1985. Grunderna för grundskolans läroplan 1985. Helsingfors: Statens tryckericentral.

Statsrådet 2006. Nationella strategin för hållbar utveckling. Helsinki.

Temmes, M. 1994. Hallinto puntarissa. Hallintouudistuksen mahdollisuudet ja edellytykset. Valtiovarainministeriö. Helsingin yliopisto. Helsinki: Painatuskeskus.

Undervisningsministeriet 1991. Plan för utveckling av utbildningen och av forskningen vid högskolorna för åren 1991-1996. Helsingfors: Yliopistopaino.

Undervisningsministeriet 1995. Utbildning och forskning 2000. Plan för utveckling av utbildningen och av forskningen vid högskolorna för åren 1995-2000. Helsingfors.

Undervisningsministeriet 1999. Utbildning och forskning 1999-2004. Utvecklingsplan 29.12.1999.

Utbildningsstyrelsen 1994. Grunderna för grundskolans läroplan 1994. Helsingfors: Tryckericentralen.

Utbildningsstyrelsen 2004. Grunderna för läroplanen för den grundläggande utbildningen 2004. Vammala: Vammalan Kirjapaino Oy.

Windham, D. M. \& Chapman, D. W. 1990. The Evaluation of Educational Efficiency: Constraints, Issues, and Policies. In H. J. Walberg (Ed.) Advances in Educational Productivity. Volume 1 (pp. 11-20). London: Jai Press.

Yrjönsuuri, Y. \& Salmio, K. 1996. Opitaanko koulussa elämää varten? In R. Jakku-Sihvonen, A. Lindström \& S. Lipsanen (Eds.) Toteuttaako peruskoulu tasa-arvoa? (pp. 391-407). Opetushallitus. Arviointi 1/96. Helsinki: Yliopistopaino.

Åhlberg, M. 2004. Kestävän kehityksen didaktiikka. Manuscript. 